\title{
安定した砂磁州における草本植生発達の 有無を分ける要因 \\ FACTORS GOVERNING THE POSSIBILITY OF HERBACEOUS VEGETATION GROWTH ON A STABLE GRAVEL BAR
}

\author{
渡辺 敏 ${ }^{1} \cdot$ 藤田光 ${ }^{2} \cdot$ 塚原隆夫 $^{3}$ \\ Satoshi WATANABE, Koh-ichi FUJITA and Takao TSUKAHARA, \\ 1正会員 農修 建設省土木研究所 河川部河川研究室 交流研究員（テ305 茨城県つくば市旭 1) \\ ${ }^{2}$ 正会員 工博 建設省土木研究所 河川部河川研究室 室長 \\ 3 正会員 工修 建設省士木研究所 河川部河川研究室 研究員
}

\begin{abstract}
Between consecutive two floods substantially disturbing gravel bars, bare areas expanded by the former flood are gradually replaced again by vegetation areas, while the bars are stable. The prediction of vegetation growth on a stable and bare gravel bar, therefore, is essential for the assessment of habitat change in a gravel-bed river. Through field surveys on the Chikuma River, possible factors in vegetation growth on gravel bed surfaces were widely examined and compared. Survey results showed that a content of material finer than $0.075 \mathrm{~mm}$ in bed surface 'matrix' was by far the most significant factor governing whether herbaceous vegetation, which was dominant in the sites, grew or not. The content of $0-4 \%$, in particular, greatly reduced chance of the vegetation growth with a few exceptions. Formation mechanisms of matrix with the fine material was also discussed in terms of its resources and deposit, which discussion suggested the influence of catchment characteristics on the activity of instream vegetation.
\end{abstract}

Key Words : river, habitat, bare bed, non-uniform bed material, matrix, fine material, wash load, sediment resources, soil water content, capillary suction, Chikuma River, Sai River

\section{1.はじめに}

一般に、砂砅州上の植生は、一定規模以上の洪水 により流失し、その後、次の有意な洪水を受けるま での間に再び繁茂するというサイクルを繰り返す。 したがって、洪水による河床挸乱は植生発達を抑制 する重要な要因と言える1)。しかし、䚌乱をもたら した洪水後の安定した砂磷州上における植生発達速 度は種々の条件により大きく異なり、河床䚓乱の度 合いだけでは砂砂州上の植生繁茂の活性度を評価す ることは難しいようである2)。本研究は、このこと に着目し、安定した砂䂺州上での植生発達速度の違 いやその有無を支配する要因を現地調查に基づいて 見いだし、その機構解明に役立てようとするもので ある。

砂制州上の植生繁茂の活性度は、磞床河川特有の 環境であり生物生息空間としても重要な裸地砂磷州

（玉石河原）の持続性と表裏一体をなす。碩を表層 材料に持つ河道区間における持続的裸地 (玉石河原) の成立要因については生物生態学的側面からの分析 が行われている33,4)、5)。しかし、それらの多くが定
性的で空間的には断片的解釈に留まっている。これ は、洪水作用に伴う立地条件の時空間的変動という 河川特有の要素が植生の発達に対して極めて大きな 影響力を持ち、この要素の定量的把握が必ずしも十 分でなかったことも一因と考えられる。

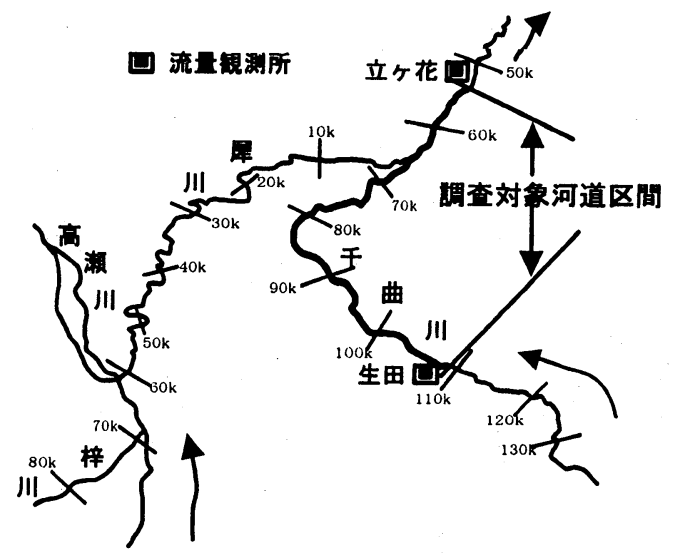

図-1 千曲川水系図と調査対象区間 


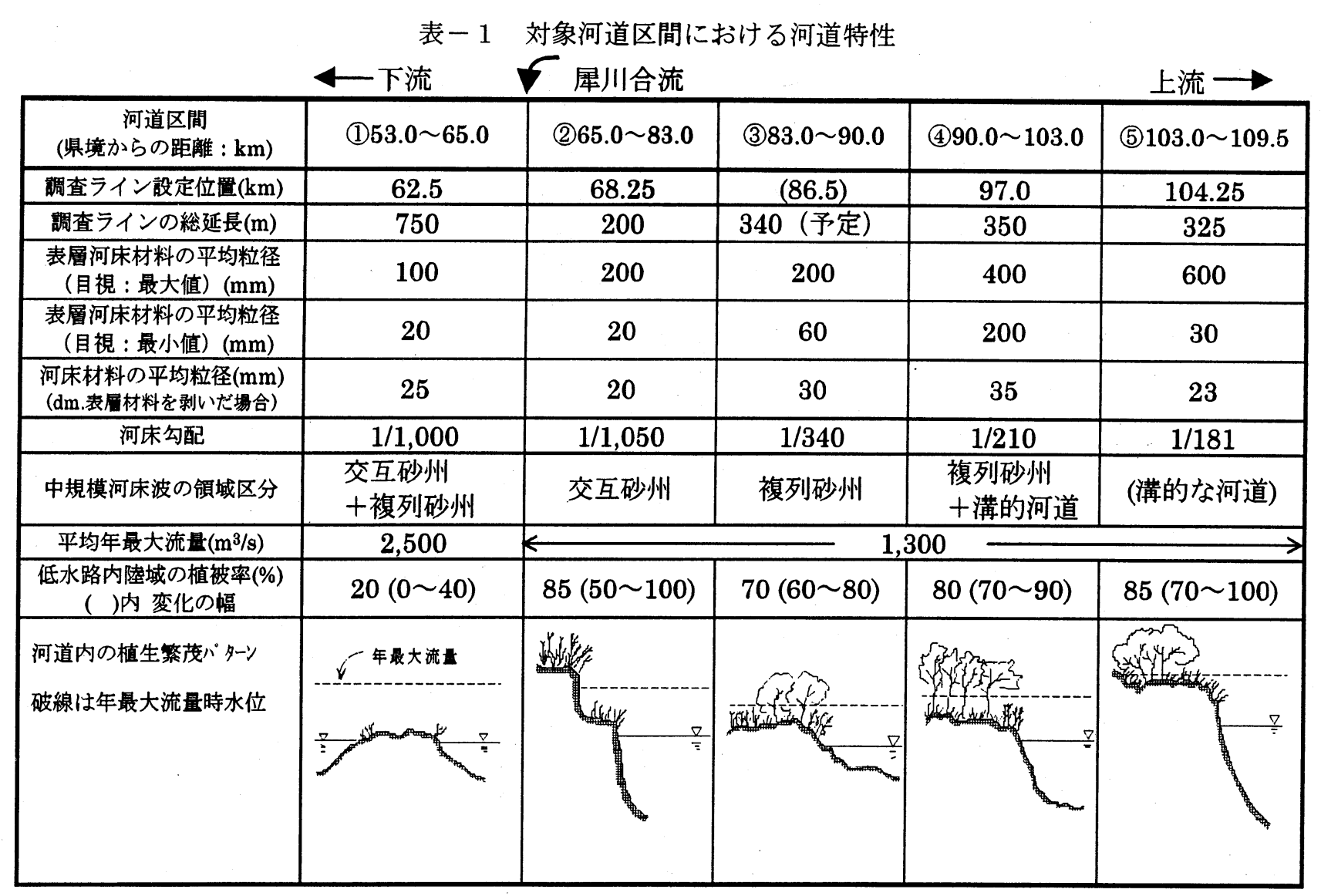

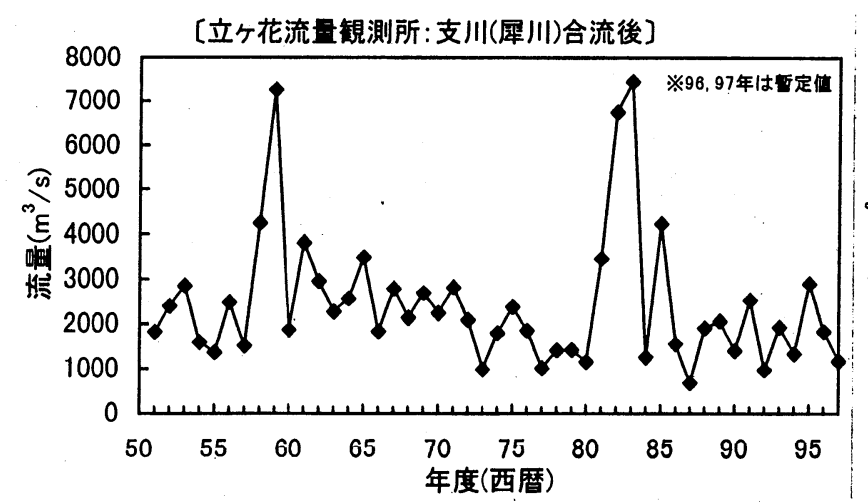

図-2 年 最大流

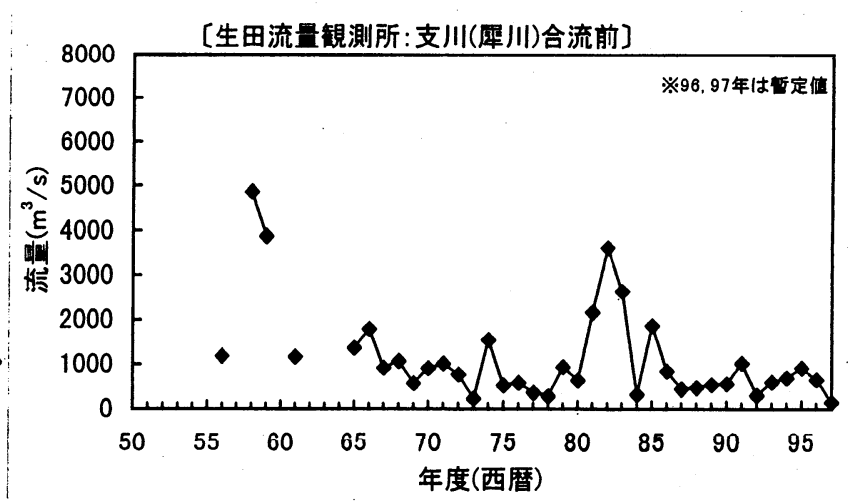

量の経 年 変化
本研究では、大きな攪乱をもたらした洪水が最近 なく、現時点まで比較的安定した河床状況が続いて いる千曲川の砂碩州を対象に、植生の発達状況とそ れに関係すると考えられる種々の要因を調べ、両者 の関係を分析した。特に、立地条件の詳細な定量記 述を行い、植生発達状況との定量的関係の把握につ とめた。本論は、以上の結果明らかになった裸地持 続に必要な要因と、それに基づく裸地持続機構の考 察結果を述べたものである。なお本研究では、調查 対象区間の砂磁州上で優勢であった草本植生を主な 検討対象とした。

\section{2. 対象河川区間と現地調査の概要}

千曲川の縦断距離標53. $0 \mathrm{~km}$ 109. $5 \mathrm{~km}$ を対象に調 査分析を行った。千曲川水系の平面図を図一1に示す。
表-1は、河道特性に関する山本の方法 ${ }^{6}$ を参考とし て、表層河床材料粒径、河床勾配、中規模河床形態、 砂䃏州上の植生繁茂パターンなどで対象河道区間を 縦断的に(1)（5)のセグメントに区分したものである。 (1)から(5)にかけて河床構成主材料はいずれも砅であ るが、河道特性と植生繁茂状況はかなり変化する。 ただし、(1)〜(5)のいずれのセグメント区間において も、対象とした低水路内の砂踏州上に発達する植生 は同様の植物群落種によって構成されていた。なお、 同植物群落種の代表的なものは図一 $4,5,7,8$ に示すとおりである。また $65 \mathrm{~km}$ 付近では犀川が合流 する。犀川の流量規模は本川より大きく、この合流 は区間(1)とそれ以外との差異を考える上で無視でき ない要因となる。

現地調査では(1)(2)(4)(5)の各セグメントの中から代 表的な砂䃯州を 1 つないし 2 つ抽出し、その砂磁州 


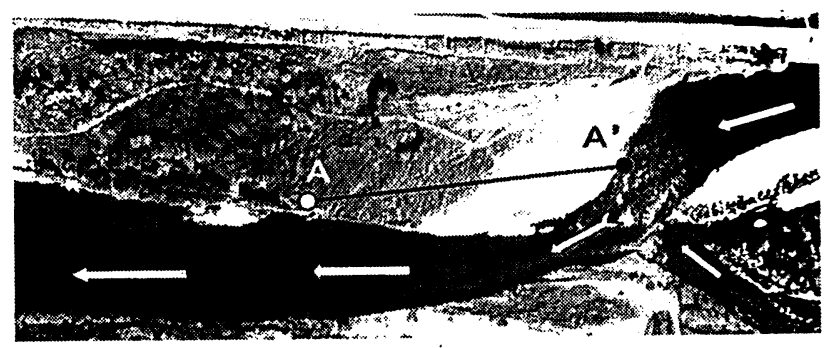

写真- 1 千曲川97.0km (1995.11撮影)

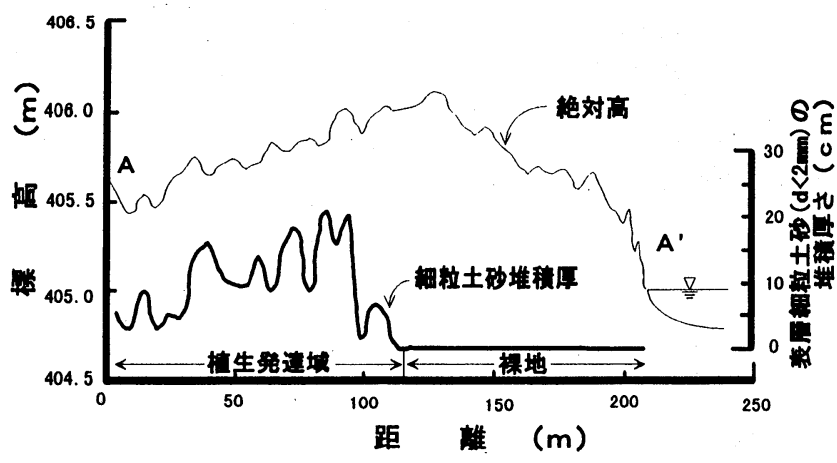

図一 $3 \quad \mathrm{~A}-\mathrm{A}$ 'ライン上の鿬面表層の 細粒土砂堆積厚さ

を概ねカバーするような調查ラインを縦断・横断そ れぞれの方向に設置した。このライン上で $0.5 \sim 1 \mathrm{~m}$ の均等間隔で植生の発達状況、表層河床材料の状況 等を定量的に測定し、同時に地形測量を行った。 1 調査範囲のライン延長は200〜 $800 \mathrm{~m}$ 程度、セグメン ト(1)(2)(4)(5)に対応した 4 範囲すべてのライン総延長 は2km弱である。各セグメント内では砂礫州とその 上での植生繁茂の基本的特徴が似通っており、1つ のセグメントについて 1 〜つの砂䃯州抽出であっ ても、十分な代表性があると判断した。調査は、 1997 年 6 月と 8 月、9 月に行った。

図-2は生田地点と立ヶ花地点の年最大流量の経年 変化であり、平均年最大流量を大きく越える洪水は 1985年以降生じていないことがわかる。さらに、横 断測量結果、平成 7 年撮影の空中写真と現在の状況 との比較から、各調査ラインについて1997年 9 月ま での少なくとも 2 年間は植生破壊を大規模に起こす ような地形変動が起こっていないことを確認した。 したがって本調査では、大きな膡乱をもたらした洪 水から 10 年以上経ち、最近 2 年間以上安定な状態に

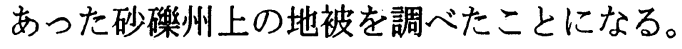

\section{3. 植生域と裸地持続域との立地環境の違い}

\section{（1）表層細粒土層の有無と植生の発達}

写真-1に示す $\mathrm{A}$ - $\mathrm{A}$ 'はセグメント(4)に設定した 調査ラインの 1 本であり、図-3に A - A'ライン表 層の細粒土砂堆積厚さを示した（ここで細粒土砂は

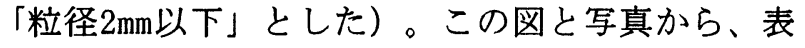
層に細粒土砂が堆積する場所では植生が発達してい ることがわかる。この性質は、調查ラインすべてに ついて見られ、砂䃋面上に細粒土砂がまんべんなく

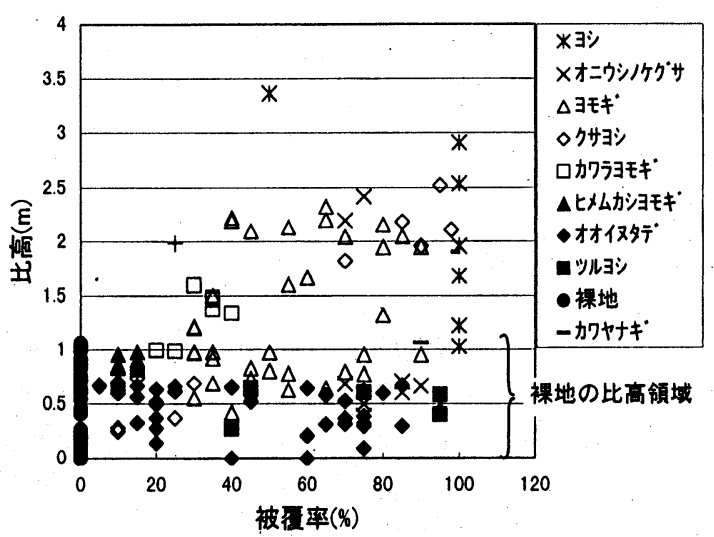

図一 4 裸地と植生域の平水位からの比高比較

堆積した場所では、強い人為的影響がない限り植生 の急速な発達が促される傾向が認められた。このこ とは、表層細粒土層の有無が植生繁茂を支配する重 要な要因の 1 つであることを示すものであり、これ については本ら゙が詳細に検討を加えている。

しかし、調査対象河道区間の低水路内においては、 表層細粒土層が見られる籁囲は限定されており、こ の土層が無く河床表面に碩がはっきり存在する場所 の方が一般的であった。そして、そのような場所に 裸地は存在するが、一方で植生が繁茂する領域も数 多く存在していた。そこで、以下では、表層細粒土 層が無い（碩が表面に露出する）領域に絞って、植 生の有無を分ける要因を分析する。

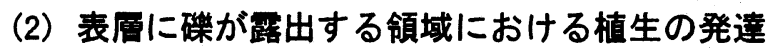

a）平水位からの比高と植生発逵との関係

まず、植生発達を左右する立地条件として平水位 からの比高を取り上げた。本分析では、平水位とし ての代表性が高いと判断された 6 月調査時点の水位 を基準とした。図-4に、調査ライン上各点の植被率. と平水位からの比高を、裸地および植生群落ごとに プロットした結果を示す。この図から、ツルヨシ群 落、オオイヌタデ群落、ヒメムカショモギ群落の成 立立地の比高範囲は裸地のそれとほぼ重なっており、 ヨモギ群落、クサヨシ群落の比高範囲についても、 裸地の比高範囲と重複する部分が相当ある。このこ とは、比高が裸地と植生繁茂域を分ける決定的な要 因としては不十分であることを示すものである。平 水位からの比高は概ね冠水頻度に対応していること から、図-4は、安定した砂砅州（低水路内の陸域） における植生発達域の有無が冠水頻度とはあまり関 係なく決まることを説明するとも言える。

b) 喽粒径亡植生発達との関係

図-5に、河床表面の主構成材料をなす砅の平均粒 径を線格子法 ${ }^{8}$ により調べ、植生発達状況と対応づ けた結果を示す。図の横軸は、裸地あるいは植生群 落ごとの調査地点数の累加度数である。この図から、 植生発達域と裸地域の砅粒径分布がほぼ重なってお り、䃯粒径が植生発達の有無を分ける主要因にはな らないと判断できる。 


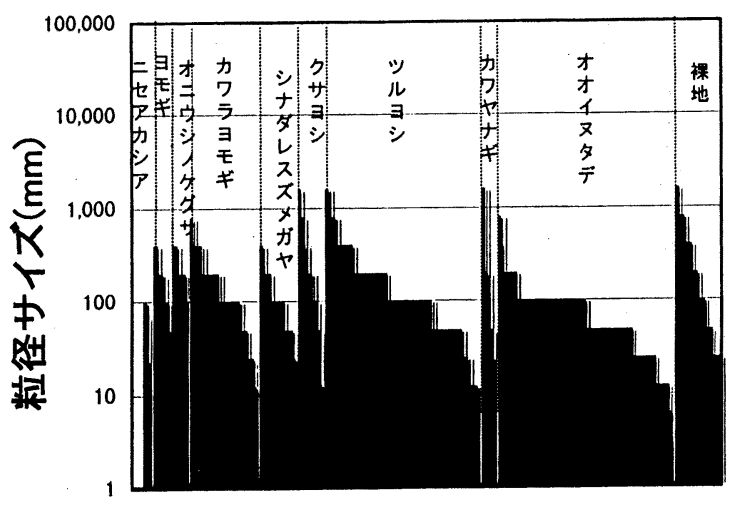

図一 5 裸地と植生発達域の表層碟粒径

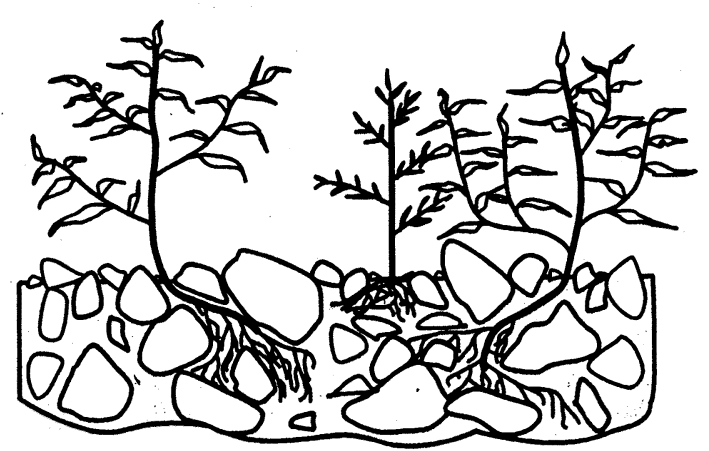

図一 6 表層に碟が露出する領域における植物の生育

c) 喽間除中の小粒径材料（マトリクス）の性質と植 生発達との関係

表面に磁が露出する領域における植生繁茂は、植 生の根がマトリクスに侵入することにより成り立っ ている（図-6参照）。そこで、表層マトリクスの重 要性に着目して、その性質と植生発達との関係を調 べた。以後分析を行っているマトリクスのデータは、 表層砂間、そこにマトリクスが無いときは砅を 1 層 はがして現れるマトリクスの材料特性を調べたもの でめり、これを表層マトリクスと呼ぶ。

図-7 は表層マトリクスの主成分（ここでは $0.075 \mathrm{~mm}$ 以下の成分を除いたものと定義）の平均粒 径について、図-5と同じ整理をしたものである。こ の図から、裸地域の表層マトリクス主成分の方が植 生発達域のそれよりも粗粒である傾向は若干うかが える。しかし、両者の分布が重複している部分も相 当あり、表層マトリクス主成分の平均粒径だけから 植生発達域と裸地域を判別するのは難しい。

一方、図-8は、表層マトリクスのうち、図-7では 取り除いたシルト粒径以下（0.075mm以下）の土砂 含有率（以後、細粒土砂含有率と呼ぶ）について、 図-5、7と同じ方法で整理したものである。この図 から、オオイヌタデと一部のツルヨシを除けば、裸 地域と植生域とで細粒土砂含有率の分布域が明瞭に 異なることがわかる。すなわち、表層マトリクスの 細粒土砂含有率が $4 \%$ 以下の場所のほとんどでは、 上記 2 群落種を除いて、植生の発達は起こっていな い。以上のことは、表層マトリクスの細粒土砂含有

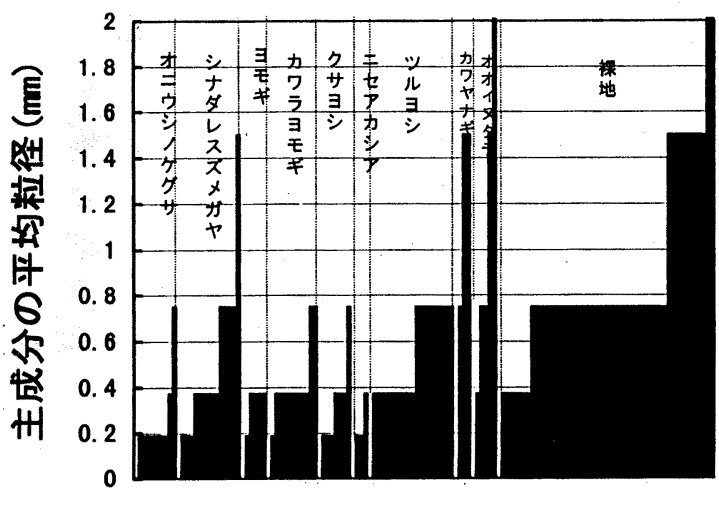

図一 7 裸地と植生域のマトリクス主材料の 平均粒径

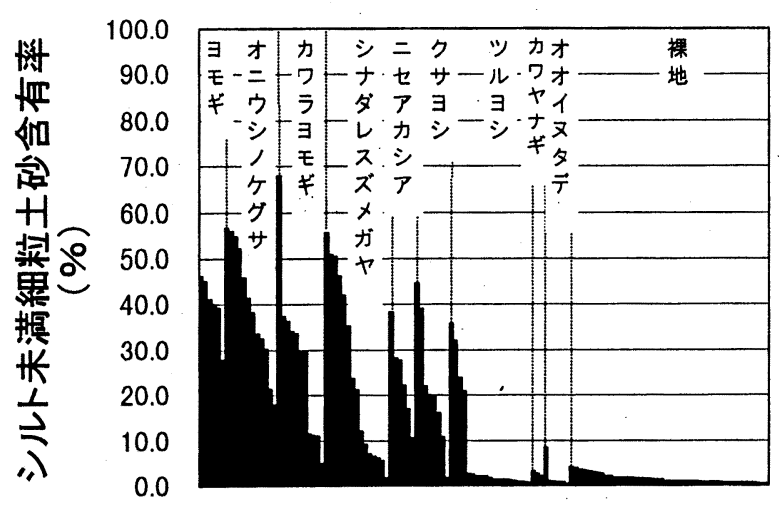

図一8 裸地と植生域のマトリクス中細粒土砂 （シルト粒径以下）含有率

率が、植生の発達の有無を分ける非常に支配的な要 因であることを示している。

ところで、調査ライン上では、碩を 2 層以上め くってもマトリクスが全くない場所があった（写真 -1の水際近くの裸地域もこの例）。これは、「透か し砅層」 ${ }^{9}$ と呼ばれる状況に対応すると考えられる。 透かし砅層状になっている場所はいずれも裸地であ り、裸地を持続させるもう 1 つの支配要因と言える。

d）表層マトリクス中の細粒土砂含有率が支配要因 となる理由について

図-9は、粒径組成が異なる代表的な 3 種類の土㖶 について、土壌水分量と $\mathrm{pF}$ 価の関係を示したもので ある（文献10）の図面に著者らが加筆）。植物は $\mathrm{pF}$ 価が約1.8〜2.8の範囲にある土壌中の水について有 効利用できるとされる10、11)、12)。図-9は、シルト粒 径以下の細かい粒子の含有率が低い土壌ほど、植物 が有効に利用できる水分が限られることを表してい る。表層マトリクスの細粒土砂含有率が裸地状態の 持続を決定づける重要な要因になる理由として、以 上のことが考えられる。透かし碩層状になっている 場所で植生が発達しない原因としては、マトリクス が現れる位置が河床表面から深く、植物の初期成長 の段階で日射が足りないこと、透かし磁層の存在に より地表付近の熱環境が植物の生育にとって厳しく なっていることが挙げられる。

ところで、図-8に示したように、オオイヌタデと 一部のツルヨシについては、表層マトリクスの細粒 


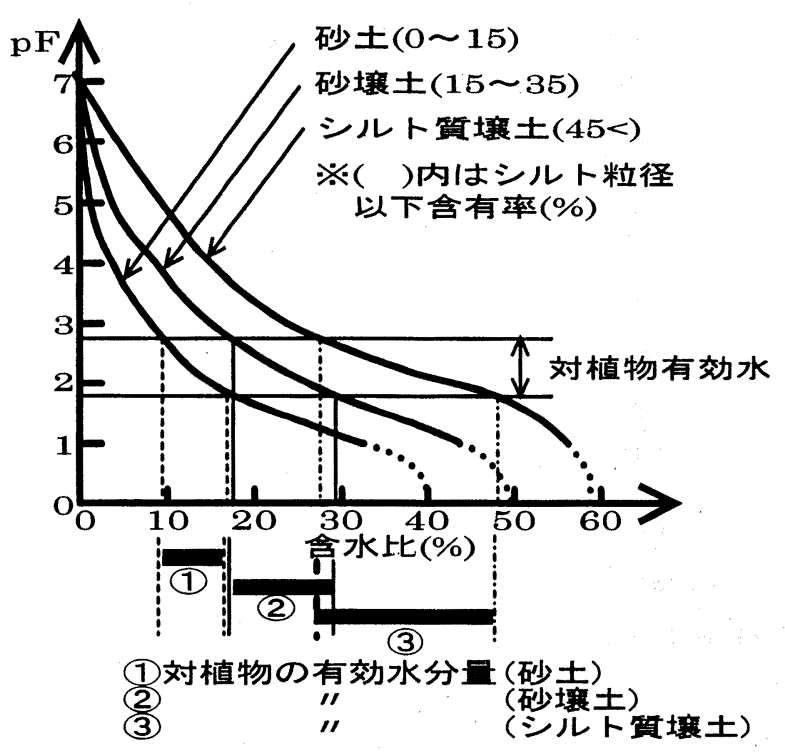

図一 9 代表的な土壤の水分特性説明図

土砂含有率が低く粒度組成が粗い場所においても群 落を形成する事例が確認できた。その例を図-10に 示す。これは、セグメント(2)に形成された中州にお いて横断方向に設けられた調查ライン上の植生分布 を示すもので、水際近くに繁茂したツルヨシとオオ イヌタデの立地面には表層細粒土層がなく、表層マ トリクスの細粒土砂含有率も $1 \%$ 以下であった。中 州の両岸の水面を結んだラインを推定地下水位線と すると、上記の植生発達域は地下水位からの比高が 小さく、中州中央の植生が柾な領域（一部では裸 地）の比高は大きいことがわかる。このことは、マ トリクスが細粒分を含まない粗い成分で構成されて いても地下水位からの比高が小さければ、特定の植 物が群落を形成できること示している。これは、水 分保持力の弱い粗粒分だけで構成されるマトリクス であっても、地下水位が十分に高い条件にあれば、 植物の発芽や成長に必要な水分が供給されるためと 考えられる。

\section{4. 表層マトリクスに細粒土砂が混じる理由の 考察}

以上から、碩が露出している河床表面における植 生繁茂の有無を支配する要因として、表層マトリク スの細粒土砂含有が重要である可能性が示された。 そこで、この理由について考察する。

\section{（1）植生による流速低減効果}

第一に、植生自身の流速低減効果によって裸地で は堆積しない細粒土砂が堆積したというシナリオが 考えられる。しかし、塚原ら ${ }^{13)}$ が扇状地河道（セグ メント(4)と(5)) と碟を河床材料に持つ自然堤防帯の 河道（セグメント(1)〜 (3)）の代表的な諸元、水理量 を用いて行った植生の細粒土砂堆積効果の概算によ ると、ウォッシュロード供給量が相当大きい条件で も、粗粒のシルトが植生効果により堆積するには、

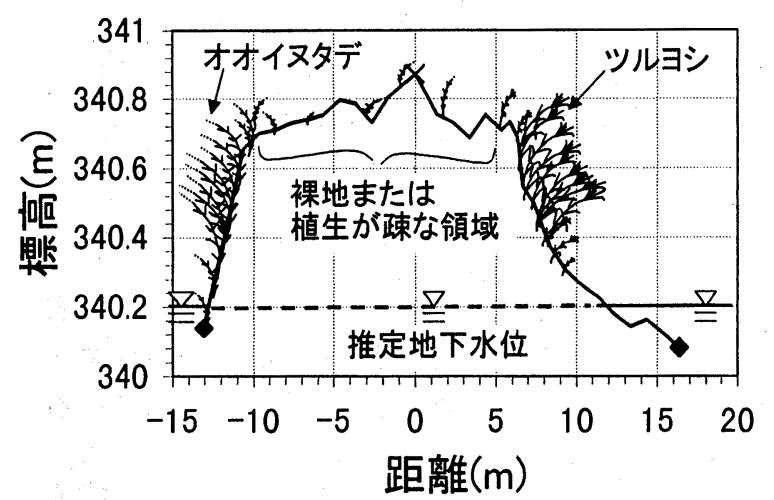

図-10 千曲川 $68.25 \mathrm{~km}$ 中州の横断形状と植生分布

扇状地河道（セグメント(4)と(5)）で $\mathrm{K}=1 \mathrm{~m} / \mathrm{s}$ 程度以下、 磁を河床材料に持つ自然堤防帯の河道（セグメント (1)〜 (3)) でK=4m/s程度以下という条件が必要となる。 ここでK:植生の透過係数である（小さい方がより密 生)。本調査においては、あわせて植生の透過係数 も計測しており、それによれば、河床表面に䂰が露 出している場所の植生のK值は全般的に高く、密生 度が高いものについて流水中の倒伏を考慮しても $5 \mathrm{~m} / \mathrm{s}$ 以上である。以上から、本調查対象については、 セグメント (1)〜 (5)のいずれの領域においても、植生 による流速低減効果が細粒土砂混入の主たる要因で あったとは考えにくい。

\section{（2）横断方向の河床高変化による細粒土砂の移流拡 散}

この機構によれば、水際部に細粒土砂が堆積でき る。ただし、藤田らは年、、その堆積量が一般に微少 であり、地形変化の要因としては考えにくいとして いる。しかし、ここで取り上げているのは、表層マ トリクスへの細粒土砂の混入であり、図-8に示すよ うに5\%というわずかな混入でも植生発達に影響を 与える。以上から、このシナリオは、細粒土砂の表 面への供給という側面については有効となる可能性 がある。ただし、マトリクス中への細粒土砂の混入 については別のメカニズムを必要とする。

\section{（3）流域特性の影響}

セグメント(1)では他のセグメント区閒よりも持続 的裸地領域の広がりが圧倒的に大きい（表一1「低 水路内陸域の植被率」参照）。そこで、セグメント (1)とセグメント(2)〜(5)の低水路内陸域における裸地 の割合が違う理由について考察した。

セグメント(1)とセグメント(2)〜(5)の持続的裸地領 域を比較すると、景観的な色彩が異なることが挙げ られる。すなわちセグメント(1)の裸地は白さが強く、 一方(2)〜(5)の裸地はこれに黒さが加わり灰色っぽく みえる。現地で採取してきた表層マトリクスを比較 してもこの傾向は明らかであり、全体としてセグメ ント(2)〜(5)の区間の細粒土砂には黒さが強いものが 多く含まれ、セグメント(1)では白い粗砂 $(0.5 \sim 1 \mathrm{~mm})$ が細粒土砂の主成分となっており全体的に白さが強 い。この原因として考えられるものとして供給土砂 
の質的違いが挙げられる。対象区間の河道特性で説 明したとおりセグメント(1)は犀川の合流を伴い、流 量は約 2 倍になる。したがって、セグメント(1)にお いては犀川合流による供給士砂の質的違いの影響を 無視できない。

セグメント(2)〜(5)の集水域の特色として黒ボク土 壤群が広く分布することが挙げられる ${ }^{15)}$ 。一般に黒 ボク土裹は火山灰を主な母材とし、褐色森林土壌等 と比較してシルトや粘土の細粒分が多いとされる土 性を持つ土壤である ${ }^{16)}, 17$ 。 。た、高瀬川、梓川を支 川にもつ犀川流域の特色として、極めて起伏の大き な飛騨山地を水源にもち、この飛騨山地北半分のほ ぼ全域は花崗岩質岩石高瀬型に覆われる ${ }^{15)}$ 。多くの 場合、花崗岩類は深部にまで砂粒風化（マサ土化作 用）を受けており、破砕が著しく流水により侵食さ れやすいとされる。そして花崗岩類の構成鉱物は石 英、長石類を主体にしており粒子は粗く硬い岩石で あるため、基岩から砂へと著しく不連続な風化過程 を持つが、これ以上の細粒化は物理的な風化作用で は殆ど起こらないとされる18)。

以上から、セグメント(1)と他のセグメントにおけ る細粒土砂の質的違いを、上述の 2 つの集水域にお ける表層土壤、表層地質特性の違いの表れとして理 解することも可能である。3 章で、裸地状態が維持 される条件として、植物の発達基盤に含まれるシル 卜以下の細粒分が少ないことが最も重要な要因であ ることを示した。「セグメント(2)〜(5)はセグメント (1)と比較してシルト以下の細粒土がより高い割合で 供給されるため、持続的裸地領域が形成される平面 スケールが小さくなる」と推測すると、犀川合流の 上下流で植生繁茂の活性度が大きく異なることが定 性的には説明しうる。このシナリオに従えば、供給 土砂の質的な違いが持続的裸地領域の造成スケール に反映されることが示唆される。

\section{5. まとめ}

安定した砂磒州（低水路内の陸域）における草本 植生発達と裸地域持続の要因について、千曲川緹断 距離標 $53.0 \mathrm{~km} \sim 109.5 \mathrm{~km}$ での調査と分析に基づき得 られた知見を以下に列挙する。

1）砅面表層に細粒土砂がまんべんなく堆積すれば、 裸地状態は維持されず植生が発達する。

2）砅が河床面に露出する領域においては、表層マ トリクス中の粒径組成が裸地状態の持続を決定 づける重要な要因であり、シルト以下の細粒分 含有率が $5 \%$ に満たない場合、ほとんどの場所 で裸地状態が持続するとの結果が考えられた。

3）ただし2）を満たす条件でも、地下水位が十分に 高ければ特定の植物は群落を形成できる。

4）河床面に砂砟が露出している場所について、碩 粒径、表層マトリクスの平均粒径、地下水位か らの比高は、植生発達域と裸地域を分ける十分 な要因とはならない。このことから、冠水頻度
は裸地域の持続と有意な相関は無いようである。

5）犀川合流前と異なり、合流後の河道区間では広 い持続的裸地領域が形成されており、この理由 を説明する仮説、すなわち「千曲川上流と犀川 上流の流域特性の違いによる供給土砂の質的な 違いが持続的裸地領域の造成スケールに反映さ れた」との考え方を示した。

6）以上の知見は、洪水による大きな靦乱が無い期 間の安定した砂磷州における植生発達と裸地持 続を予測する手法を検討する上で有用である。

謝辞 : 望月達也 前河川研究室長からは有益な助言 をいただきました。本研究は河川生態学術研究会の 一環として行った調查研究をとりまとめたものであ ります。なお本研究を進めるにあたって、水位、流 量、航空写真、横断測量等のデータを、建設省北陸 地方建設局千曲川工事事務所加提供して頂きまし た。ここに記して感謝の意を表します。

\section{参考文献}

1)たとえば、塚原隆夫, 渡辺 敏, 望月達也, 藤田光一： 喽床河川における水辺環境の変化之洪水の作用, 土木 技術資料, Vol.39/No.5, pp.30-35, 1997.

2) 渡辺敏 : 河川における植生の変動過程に関する研究, 土木技術資料，Vol.40/No.1，1998. （印刷中）

3) 石塚和雄: 植物生態学講座 1 群落の分布と環境, 朝倉 書店, pp.237-242, 1977.

4) 宮脇昭: 日本の植生, 学研, pp.52-57,1977.

5) 奥田重俊, 佐々木寗 : 河川環境 と水辺植物一植生の保 全と管理一, ソフトサイエンス社, pp.29-31， 1996.

6) 山本晃一: 沖積河川学, 山海堂, pp.1-16, 1996.

7) 李参熙, 藤田光一, 塚原隆夫ほか: 喽床河川の樹林化 に果たす洪水と細粒土砂流送の役割, 水工学論文集, 第42卷, 1998 (投稿中) .

8)山本晃一: 砂砅河床のサンプリングと統計的処理, 土 木技術資料，Vol.13/No.7，pp.40-44， 1971.

9) 池田宏：透唩層の成因に関する水路実験, 地形, 第3巻 第1号, pp.57-65, 1982.

10) 中野秀章: 水文学講座 13 森林水文学, 共立出版, pp.121-125, 1979.

11)中野政詩: 土の水分量と毛管張力の関保(脱水過程) 2 , 農業土木学会論文集, 第35号, pp.10-14, 1971.

12)小橋澄治, 村井宏, 亀山章: 環境緑化工学, 朝倉書店, pp.9-21.1992.

13)塚原隆夫, 藤田光一, 望月達也 : 植生が繁茂した河川 水際への細粒土砂堆積の特性, 第3回河道の水理と河川 環境に関するシンポジウム論文集, pp.259-264， 1997.

14)藤田光一, John A. MOODY, 宇多高明, 藤井政人： ウォッシュロードの堆積による高水敷の形成と川幅縮 小, 土木学会論文集, No.551/II -37, pp.47-62, 1996.

15)経済企画庁総合開発局: 土地分類図(長野県), 1974.

16)浅海重夫 : 土埵地理学一その基本概念と応用, 1990.

17)河田弘: 森林土壤学概論, 博友社, 1989.

18)三木幸蔵 : わかりやすい岩石之岩盤の知識, 鹿島出版 会, 1979 .

(1997. 9. 30受付) 